\title{
The (Misunderstood) Genius of American Corporate Law
}

Robert B. Ahdieh

Texas A\&M University School of Law, ahdieh@law.tamu.edu

Follow this and additional works at: https://scholarship.law.tamu.edu/facscholar

Part of the Business Organizations Law Commons, Commercial Law Commons, Law and Economics Commons, and the Law and Society Commons

\section{Recommended Citation}

Robert B. Ahdieh, The (Misunderstood) Genius of American Corporate Law, 77 Geo. Wash. L. Rev. 730 (2009).

Available at: https://scholarship.law.tamu.edu/facscholar/1220

This Article is brought to you for free and open access by Texas A\&M Law Scholarship. It has been accepted for inclusion in Faculty Scholarship by an authorized administrator of Texas A\&M Law Scholarship. For more information, please contact aretteen@law.tamu.edu. 


\title{
Reply
}

\section{The (Misunderstood) Genius of American Corporate Law}

\author{
Robert B. Ahdieh* \\ The genius of American corporate law is in its \\ federalist organization. ${ }^{1}$
}

With this simple aphorism, Roberta Romano artfully captures the prevailing expectation of corporate scholars that state competition will advance some movement-be it a race, a leisurely walk, or a crawl-toward "the top" in corporate governance. In Trapped in a Metaphor: The Limited Implications of Federalism for Corporate Governance, I challenge this expectation. ${ }^{2}$ Unlike others, I do not insist that state competition actually drives a "race to the bottom."3 Nor do I argue, like a number of recent works, that there is little or no race at all. ${ }^{4}$ Rather, I suggest that debates over the "race" in corporate law

* Professor of Law and Director, Center on Federalism and Intersystemic Governance, Emory University School of Law; Visiting Professor of Law, Georgetown University Law Center; Visiting Scholar, Institute for Advanced Study.

1 Roberta Romano, The Genius of american Corporate law 1 (1993).

2 See Robert B. Ahdieh, Trapped in a Metaphor: The Limited Implications of Federalism for Corporate Governance, 77 GEO. WASH. L. Rev. 255 (2009).

3 See, e.g., Lucian Bebchuk et al., Does the Evidence Favor State Competition in Corporate Law?, 90 CAL. L. Rev. 1775 (2002); William L. Cary, Federalism and Corporate Law: Reflections Upon Delaware, 83 YALE L.J. 663 (1974).

4 See, e.g., Michael Abramowicz, Speeding Up the Crawl to the Top, 20 Yale J. ON REg. 139 (2003); Lucian Arye Bebchuk \& Assaf Hamdani, Vigorous Race or Leisurely Walk: Reconsidering the Competition Over Corporate Charters, 112 YALE L.J. 553 (2002); William W. Bratton, Corporate Law's Race to Nowhere in Particular, 44 U. Toronto L.J. 401 (1994); Marcel April 2009 Vol. 77 No. 3 
misunderstand its destination. They fail, as such, to engage the actual function of federalism in the operation and regulation of the modern public corporation.

In the preceding pages, three thoughtful scholars offer their responses to this claim. I only regret that I did not have the benefit of their insights as I authored the original piece. Had I, it would undoubtedly have been strengthened. With their reactions now in hand, however, let me take advantage of this opportunity of reply, to clarify precisely what it is that I aim to suggest.

At the outset, it bears acknowledging that my argument is primarily directed to the scholarly discourse of corporate law. ${ }^{5}$ While the analysis I offer holds implications for questions of policy and regulation in the governance of the modern public corporation, its immediate emphasis is on the ways in which we talk about federalism and state competition in corporate law; hence, my focus on the problematic metaphor of a "race."

Even as to the corporate law literature, however, it was not my intention to cast it as exclusively directed to questions of federalism and state competition. ${ }^{6}$ On this count, I am guilty of some overstatement, as Professor Cunningham appropriately emphasizes. ${ }^{7}$ I may even, I will concede, have been inartful in some of the framing of my argument.

On the other hand, I remain confident in my basic claim that the corporate literature has put an exaggerated emphasis on the place of federalism and state competition in corporate law. Consider a bit of casual empiricism, inspired by Professor Henderson's efforts ${ }^{8}$ at the latter: Focusing on a collection of "top ten" journals, ${ }^{9}$ a search for published articles including the word "securities" or some term begin-

Kahan \& Ehud Kamar, The Myth of State Competition in Corporate Law, 55 STAN. L. Rev. 679 (2002).

5 See William W. Bratton, Unentrapped, 77 Geo. WASH. L. Rev. 677, 678-79 (2009) ("The negaiive, as Professor Ahdieh acknowledges, less concerns corporate law itself than academic discussions thereon.").

6 Cf. id. at 679; Lawrence A. Cunningham, The New Federal Corporuition Lan?, 77 GEê. WASH. L. REv. 685, 686 \& n.14, 695-96 (2009).

7 See Cunningham, supra note 6, at 692-96.

8 See M. Todd Henderson, Two Visions of Corporate Law, 77 GeO. WASH. L. ReV. 708, 709 \& n.3 (2009).

9 I included the California Law Review, Columbia Law Review, Harvard Law Review, Michigan Law Review, New York University Law Review, Northwestern University Law Review, Stanford Law Review, University of Chicago Law Review, University of Pennsylvania Law Review, and Yale Law Journal. I leave it to those more empirically minded than myself to critique the election of this particular set of journals. 
ning "corporat-" over the last decade yielded 4162 hits. Of those articles, in turn, almost three-quarters (2906) make at least some reference to "Winter" or "Cary," to a "race," or to "federalism," "federalist," or "state competition." 10 A further search of the same journals over the same period yielded 218 articles with "securities" or "corporat-" in the title. A subsequent search for articles with the latter in text and one of the above "federalism" terms (e.g., "Winter," "Cary," "race") in the title, meanwhile, yielded 129 articles-offering further suggestion of the importance of federalism questions in the corporate literature.

Given the self-evident limits of this empirical frolic and detour, ${ }^{11}$ however, the centrality of federalism to the corporate law discourse might be better evidenced by the literature's broad characterizations of federalism's role-as in its place as "the genius" of American corporate law. ${ }^{12}$ Beyond such rhetoric, one might also ask what we would expect a neophyte reader to take away from an encounter with the modern corporate literature. What role would she understand federalism and state competition to play in American corporate law? If not necessarily its genius, surely she would understand at least the critical dimension of its institutional design. Even more significant would be her likely sense of state law as a "default rule" of sorts in corporate law, against which any proposed intervention by federal authorities must overcome a prima facie burden. ${ }^{13}$ Ultimately, it is this approach to federalism in the corporate law literature that I would condemn.

I do not argue, as such, that we should federalize corporate lawlet alone that such federalization would ensure optimal results. It may not. My objection is rather to the claim that it cannot yield optimal

10 I chose to exclude the term "federal," on the theory that it might skew the results.

11 A better empirical indication of federalism's importance to the corporate literature might be found in the fact that, at least in some recent years, a third or more of the Corporate Practice Commentator's annual list of top corporate and securities articles have included discussion of the race debate.

12 I am thus in full agreement with Professor Bratton's suggestion of federalism's orthogonal relationship to the three areas of debate in corporate law that he highlights. See Bratton, supra note 5, at 680-81. It is the inconsistency between this limited relationship and the corporate literature's strong emphasis on federalism that I seek to emphasize. As Professor Bratton forcefully puts it, with reference to debates over shareholder-managerial relations, "the federalism reference determines nothing. No serious advocate of management discretion can rest the case on charter market constraints. Standing up to shareholder primacy requires an affirmative defense based on economic and governance fundamentals." Id. at 681.

13 I am grateful to Professor Cunningham for his suggestion of this "burden of proof" frame of analysis for thinking about my objections to the existing literature, and about the alternative I propose. See infra notes $40-41$ and accompanying text. 
results. My question, as such, is whether so heavy a finger should be placed on the scale in favor of state law. ${ }^{14}$

It is not my claim that federalism is irrelevant to the operation and regulation of the modern public governance. ${ }^{15}$ To the contrary, I am even ready to acknowledge its potential "genius."16 I simply suggest that it does not speak - at least in any direct way-to the questions of corporate governance that are conventionally characterized as the heart of corporate law. ${ }^{17}$ In my account, then, federalism has a valuable role to play. It simply should not be understood to advance efficiency in shareholder-managerial relations. ${ }^{18}$

Federalism and state competition serve an important function in promoting efficient behavior by regulators ${ }^{19}$ _as opposed to the managers whose behavior has been the emphasis of corporate law since Berle and Means wrote of "the separation of ownership and control," some seventy-five years ago. ${ }^{20}$ State competition may thus help to foster an efficient allocation of wealth between the state and the firm as a whole, even if it does nothing to impact distribution of the consequently expanded pie within the firm. ${ }^{21}$ It is likely to diminish the extent of regulatory shirking. ${ }^{22}$ It may encourage states to calibrate their legal reforms to achieve an efficient equilibrium of innovation and continuity. ${ }^{23}$ It may likewise promote investment in relevant institutions, including commercial courts and effective corporate lawmak-

14 Professor Henderson suggests that my argument "may provide Delaware's enemies with the ammunition they need to win the war against state corporate law." Henderson, supra note 8, at $711 \mathrm{n} .14$. Whether or not I am an arms dealer in Henderson's war, the argument herein does not dictate any conclusion in favor of federal corporate law.

15 See Bratton, supra note 5, at 683 (noting that federalism's "secondary" role does not make it "irrelevant or trivial").

16 See Ahdieh, supra note 2, at 283-84.

17 See, e.g., Romano, supra note 1 , at 1 ("[C]orporate law . . concerns the relation between a firm's shareholders and managers ....").

18 I might thus resist my placement in the "expertise" (versus "markets") camp described by Frufessor Hentersun with reference to Thomas Sowell. See Henderson, supra note 8, at 712. My position is simply that the corporate iiticature souid du bctter than it commonly has in recognizing the appropriate province of each.

19 "Efficient" belongs in scare quotes here, given the far more ambiguous welfare implications of the distribution of wealth between state and firm, as opposed to manager and shareholder. See Ahdieh, supra note 2, at 289-90.

20 See Adolf A. Berle, Jr. \& Gardiner C. Means, The Modern Corporation and Private Property 84, 115, 128-40 (1932); see also Ahdieh, supra note 2, at 258-59.

21 See Ahdieh, supra note 2, at 259.

22 See id. at 289.

23 See id. at $286-87$. 
ing bodies within the legislature. ${ }^{24}$ And, of course, it can be expected to move tax rates closer to the marginal cost of services provided. ${ }^{25}$

With such a broad enumeration of federalism's contributions, have I embraced the traditional account? Is this not all that advocates of federalism's role in corporate governance see it to accomplish as well? No, and no. What I describe of the role of federalism continues to diverge fundamentally from the conventional view. Consider Professor Henderson's able restatement of the latter: "[S]tate law is ultimately determinative of the nature of markets. While the market for corporate control disciplines managers, it is competition among states that disciplines states from distorting the market for corporate control." 26

It is this claim - what I characterize in Trapped in a Metaphor as the assertion of a "reinforcing" role for state competition in promoting efficient corporate governance-that I dispute. ${ }^{27}$ In Professor Henderson's account, state competition is essential to efficient corporate governance. Why? Because it ensures the enactment of rules that allow "managerial competition"-the disciplining of managers by the capital markets-to flourish. It is my argument, however, that there is no particular reason-beyond its consistent repetition-to believe this is true.

The critical question is whether managers-by way of self-help, legal reform, or otherwise-can avoid the effects of state law that is inconsistent with efficient managerial competition. ${ }^{28} \mathrm{I}$ believe, at least in the ordinary case, that they can. Professor Henderson disagrees, on the ground that "[m]uch state law, and nearly all controversial state law, is mandatory and cannot be waived." 29 But I am unsure this is true. To the contrary, much of the corporate literature would seem to turn on the nature of corporate law as constituted primarily by default

24 See id. at 287.

25 Contrary to Professor Henderson's suggestion-as the enumeration above makes clear-I do not see federalism's utility as lying solely in its reduction of franchise tax rates. See Henderson, supra note 8 , at $711 \mathrm{n} .12,717 \mathrm{n} .38$.

26 Id. at 711 ; see also id. at 717 (asserting that "markets and law work together to achieve optimal governance arrangements").

27 See Ahdieh, supra note 2, at 274-78.

28 Professor Henderson himself acknowledges as much, if only in passing, when he highlights "the ease of exit for firms, either through incorporation choice or by contract." Henderson, supra note 8, at 719 (emphasis added).

29 See id. at 717-18. The significance of the second shortcoming that Professor Henderson identifies-my lack of emphasis on the judge-made character of much corporate law-is less apparent to me. In any case, given the importance of his first critique, 1 focus on it. 
rules. ${ }^{30}$ At the extreme, of course, this is the story behind Bernie Black's account of corporate law as "trivial." 31

That said, if Professor Henderson is right-or perhaps, to cast his argument in the most favorable light, where he is right-I concede his point. Where relevant public rules (a) speak to the efficacy of managerial competition and (b) are mandatory in nature, my argument does not hold; in such circumstances, federalism and state competition directly implicate the efficiency of corporate governance. I believe, however, that this category is far more limited than Professor Henderson suggests.

By way of reference, Professor Henderson cites various rules that he conceives to meet the above criteria, including "business purpose" requirements, the traditional issuance of specific rather than general charters by state legislatures, and bans on the use of poison pills and other takeover defenses. ${ }^{32}$ As to some of these, Professor Henderson is correct. Where cast in mandatory terms, such rules are not captured by the analysis I offer. As to many of Professor Henderson's examples, however, the relevant subject matter is not corporate governance. Rather than the distribution of wealth and power between shareholders and managers, such rules constitute state impositions on the wealth of the firm generally-likely in the service of rent extractions by state authorities. Rather than a detail, this is a critical distinction. ${ }^{33}$

The question Trapped in a Metaphor considers, thus, is the relevance of state competition to shareholder-managerial relations. Can efficient regulation of managerial behavior vis-à-vis shareholdersi.e., the minimization of agency costs-be accomplished absent state competition? I posit that it can, because of the constraint on managerial behavior by the capital markets: what I term managerial competition, but is, of course, Henry Manne and Ralph Winter's innovation. ${ }^{34}$

30 See, e.g., Frank H. Easterbrook \& Daniel R. Fischel, The Corporate Contract, 89 Colum. L. Rev. 1416, 1417 (1989).

3i Sce Bernard S. Black, Is Corporate Law Trivial?: A Political and Economic Analysis, 84 Nw. U. L. Rev. 542, 551-61 (1990).

32 See Henderson, supra note 8, at 717-19.

33 See Ahdieh, supra note 2, at 283-84.

34 It bears emphasizing that my argument does not directly engage the question of capital market efficiency-and the resulting efficacy of managerial competition. As Professor Bratton points out, I simply assume it. See Bratton, supra note 5, at 682 . If this assumption proves false, then the entire argument for federalism in corporate law-dating back to Ralph Winter's response to Bill Cary-falls apart. What my contribution seeks to add is the claim that even if-as corporate federalism's advocates believe-the assumption of efficiency is true, the same result follows: federalism becomes relatively inconsequential to advancing efficiency in shareholdermanagerial relations. 
Professor Henderson-articulating the standard "reinforcement" argument-suggests that this is wrong, because state law can be expected to limit the operation of managerial competition absent regulatory competition. Yet this misses the forest for the trees. Why, thus, would we expect public authorities to act in ways that would reduce shareholder wealth? Two possibilities present themselves:

The first-on which the modern corporate literature is premised-is that they will do so at the insistence of managers, given the latter's influence on place of incorporation, and resulting ability to direct franchise tax revenues and legal work to the state. ${ }^{35}$ But let us assume-like the modern literature-that the capital markets function efficiently. If so, managers should be fully incentivized to act in shareholder interests. Why, then, would they pursue rules that harm them?

The familiar response is that managers can no longer be expected to pursue shareholder interests, if they can instead insulate themselves from competitive discipline, by way of mandatory federal law. As I suggest in the article, however, this claim does not hold up, upon further reflection: Even if managers could secure mandatory federal rules limiting managerial competition, this would avail them only so much. For, as Winter himself emphasized, the relevant motivation behind managerial competition is not limited to competition for capital among U.S. corporations, but extends to any number of other investment choices as well-from foreign equity to municipal bonds, and from real estate to certificates of deposit. ${ }^{36}$ Managers must compete against all of these potential beneficiaries of investment capital-not against other managers alone. If the efficiency of the capital markets and resulting managerial competition is the baseline, then, Professor Henderson's argument that, if not for state competition, corporate law would be riddled with mandatory provisions that limit managerial competition, falls short. Bluntly put, it lacks a theory.

If public authorities are unlikely to adopt rules harmful to shareholder interests at the insistence of managers, then, what of the second potential explanation for why they might do so? Perhaps, rather than serving managerial interests, such rules are motivated by potential rent extractions. Managerial competition, of course, does nothing to constrain this possibility. If this is the argument for federalism and state competition, however, Professor Henderson and I have no disa-

35 This, of course, was Cary's original claim. See Cary, supra note 3, at 666-70.

36 See Ralph K. Winter, Jr., State Law, Shareholder Protection, and the Theory of the Corporation, 6 J. LeGal Stud. 251, 257 (1977). 
greement. For the constraint of regulatory malfeasance, shirking, and the like-as I suspect explains much of the mandatory rulemaking that Professor Henderson highlights-is precisely the role for federalism that I acknowledge and embrace.

Again, does this concede the argument to the conventional view? Not in the least. To the contrary, it proves my point. Federalism may contribute significantly to the operation and regulation of the modern public governance. Its contribution simply has nothing to do with corporate governance.

Where, then, does this leave us? My conclusion, I understand, will necessarily be unsatisfying to some: in assessing the choice between federal versus state rules in corporate law, there is no single, self-evident answer. Comparative institutional analysis is unavoidable. Such analysis, furthermore, must be in the particular, rather than the general. It is not enough to simply assert that the federal government is a regulatory monopolist,,$^{37}$ that competition is efficient, or that regulators are susceptible to capture. ${ }^{38}$ In a sense, then, rather than suggesting we should stop talking about federalism, ${ }^{39}$ my argument might well be read to suggest that we should talk about it more. We need, however, to actually talk about it.

In this vein, I found Professor Cunningham's references to my "shrewd allocation" of the burden of proof to federalism's proponents to be instructive..$^{40}$ In a sense, this highlights the fundamental claim that I hope to advance in Trapped in a Metaphor. My critique, as emphasized above, is not directed to state rules of corporate law, nor even to resulting patterns of state competition. Rather, it is directed to the prima facie preference that such rules would seem to enjoy, in much of the modern corporate law literature. I do not suggest that we should shift the burden onto those who prefer state law, but simply that we shift it off of those who suggest the selective imposition of federal rules. From this posture, I believe, a more fair-minded analysis of the choice between federal versus state rules, in particularized settings, may be offered. ${ }^{41}$

37 See, e.g., Henderson, supra note 8, at 720.

38 It is such uncritical assertions that $I$ have in mind in my references to the corporate literature's presumption of inefficiency in federal corporate rules such as the Sarbanes-Oxley Act. See Cunningham, supra note 6 , at $686-87$.

39 See Henderson, supra note 8, at 710-11.

40 See Cunningham, supra note 6, at 692.

41 A preference for state law would seem particularly inappropriate if, as Professor Henderson suggests, "there is no easy or theoretical answer as to whether managers, shareholders, 
Such analysis-as both Professors Bratton and Cunningham rightly emphasize - has not been absent from the corporate law literature. ${ }^{42}$ And, of course, each of their responses develop examples of such analysis-including Professor Cunningham's creative exploration of what recent financial regulation reform proposals by the Treasury Department might presage about the balance of mandatory versus enabling regulation of the financial sector. ${ }^{43}$ Were we to shift away from the corporate literature's prima facie orientation to state law, I suspect we might see far more such analysis.

As Professor Cunningham's example suggests, this approach may not change our conclusions in any given case. By making greater room for counterargument, on the other hand, it at least allows for that possibility. In responding to his argument, for example, I might challenge Professor Cunningham's reliance on particular historical incidents in which federal incorporation or federal rules of corporate governance were presumed to be-and sometimes actually weremandatory in nature. ${ }^{44}$ Such incidents played out, I might emphasize, in the shadow of a strong presumption of a state regime of corporate law-and one that was perceived, at least by many, as overly lax. Further, I might cite the counterhistory suggested by the fact that, of the many proposals for mandatory federal incorporation he mentions, none were ever adopted. As Professor Cunningham has argued elsewhere, meanwhile, even where the federal government has intervened in corporate governance, it has done so in fairly muted ways. ${ }^{45}$ On a

employees, or other corporate stakeholders are more likely to get what they want from the Congress or state legislatures competing with each other." Henderson, supra note 8, at $710 \mathrm{n} .10$.

42 See Bratton, supra note 5, at 679-80; Cunningham, supra note 6, at 693-95. That said, it is striking how much of the analysis of individual issues in corporate law (e.g., the use of poison pills, shareholder voting requirements, provision for independent boards or audit committees) is framed as a question of federal versus state law. See Cunningham, supra note 6, at 694-95.

43 See Cunningham, supra note 6, at 696-707. Professor Bratton walks through a number of areas suited to a more evenhanded assessment of the choice between federal and state law, including efforts to extend the ambit of shareholder voting, see Bratton, supra note 5, at 682; questions of the precise impact of antitakeover laws, see id.; and the approach taken by the Delaware courts in the wake of threat of federal incorporation in the 1970s and the takeover battles of the $1980 \mathrm{~s}$, see id. at $682-83$.

44 See Cunningham, supra note 6, at 692, 696-97.

45 See Lawrence A. Cunningham, The Sarbanes-Oxley Yawn: Heavy Rhetoric, Light Reform (And It Just Might Work), 35 CoNN. L. REv. 915, 919-20 (2003) ("Besides enlarging the enforcer's net and mandating studies, the [Sarbanes-Oxley] Act makes no direct effort to exhort, encourage or command superior accounting or corporate governance. The Act can be seen as 'sweeping' in a modest sense concerning the number of disparate issues and groups singled out for explicit or implicit blame in the agitation prompting it."). I might also question the consistency of Professor Cunningham's account with the history of deregulation over the last halfcentury, including in the financial sector. 
clean slate, thus, enabling federal rules might plausibly be predicted to emerge as a middle ground between state law and a comprehensive and mandatory regime of federal corporate law.

My goal here, however, is not to dispute Professor Cunningham's analysis. As I understand the latter, he suggests simply that the adoption of federal mandatory rules may be more likely than I suggest. So long as the claim is not the more imperial one that I believe underpins much of the corporate law literature-the notion that federal law is necessarily mandatory or inefficient, because it arises from a regulatory monopolist, is not a product of competition, is susceptible to capture, etc.-I stand ready to be convinced.

In Professor Henderson's response, finally, one might see further hope for a discourse of comparative institutional analysis along the lines I suggest. Even in his defense of the standard claim of federalism's role in corporate governance, thus, Professor Henderson concludes with a recognition of the need to engage the question of "where to defer to markets and experts and in what proportions." 46 Between the extremes of market and expertise, he suggests, is "where the real work of corporate law is to be done." 47 In this, I read him to encourage just the effort I describe, to identify potential indicia of the likely efficacy of federal versus state rules of corporate law, in one setting versus another. ${ }^{48}$ If we can move toward an analysis of this variety-judging the appropriate place of federal versus state rules of corporate law, in particular settings, without any prima facie burden on one regime versus the other-I suspect we may achieve at an even richer discourse of corporate law.

46 Henderson, supra note 8 , at 728 .

47 Id. at 728-29; see also id. at 712 ("The more choice is real and readily available, the less work there is for experts to tinker at the edges. It follows, of course, that the less choice available in the market, the more intervention that may be needed.").

48 See Ahdieh, supra note 2, at 301-02. I even find appeal in Professor Henderson's construction of the relevant analysis as in the nature of antitrust: "The question isn't whether states are racing but whether the market tor iaw is working. Thr is an antitrust-like analysis, because the measurement is one of competition and choice. If there are low switching costs, ease of entry, no legal barriers, abundant choice, and so forth, or if the market for law can be improved by adjusting the process of lawmaking, then it is much harder to justify substituting expertiseand vice versa." Henderson, supra note 8, at 713; see also id. at 728-29. As this construct makes clear, Professor Henderson's framework-by contrast with mine-continues to put a finger on the scale in favor of state law. By comparison with the dead weight placed on it by much of the corporate law literature, however, I count Professor Henderson's light touch as a significant move in the right direction. 